\title{
TEKNIK PERSUASIF BUNG TOMO PADA PIDATO 10 NOVEMBER 1945 DI SURABAYA
}

\author{
Lutfi Alvian Widianto \\ STID Al-Hadid, Surabaya \\ lutfialvianw@gmail.com
}

\begin{abstract}
Abstrak: Para dai memiliki tugas untuk mengubah mad'uw dari buruk menjadi lebih baik dalam berdakwah. Agar sukses dalam mengubah mad'uw menjadi manusia yang lebih baik, para dai dituntut untuk memiliki kemampuan persuasif. Ada sebuah realitas kesuksesan seseorang yang bukan dai, namun beliau mampu menggerakkan massa. Dia adalah Bung Tomo yang mampu menggerakkan rakyat Surabaya utamanya yang beragama Islam untuk berani melawan Inggris yang memiliki kekuatan militer jauh lebih canggih dan tentaranya terlatih. Dari realitas kesuksesan pidato Bung Tomo tersebut diharapkan menjadi contoh bagi para dai dalam melakukan dakwah persuasif. Studi ini bertujuan mengetahui teknik persuasif yang diterapkan oleh Bung Tomo dalam pidato 10 November 1945 di Surabaya. Teori yang digunakan adalah teori Teknik Persuasif. Metode yang digunakan adalah deskriptif kualitatif, data-data diperoleh dari dokumen berupa website dan telah dilakukan triangulasi data. Hasil kajian menunjukkan bahwa pada pidato 10 November 1945, Bung Tomo menggunakan (1) teknik integrasi dalam menunjukkan persamaan nasib yang dialami oleh Bung Tomo dengan warga Surabaya, (2) teknik ganjaran dalam menunjukkan bahwa kemenangan perang akan diperoleh, (3) teknik tataan yang terlihat dari gaya bahasa yang digunakan oleh Bung Tomo seperti gaya bahasa perulangan dan metafora.

Kata Kunc : teknik persuasif, pidato Bung Tomo 10 November 1945, dakwah
\end{abstract}

Bung Tomo's Persuasive Technique of Speech on November, $10^{\text {th }}, 1945$ in Surabaya. Abstract: Dai / propagators have a duty to change mad'uw / audience from doing something bad into doing something good by da'wah. In order to succeed in changing mad'uw to be better people, da'i are demanded to have a persuasive skill. There is a reality of a figure who succeeded to move people persuasively though he isn't da'i. He is Bung Tomo, a notable figure who succeeded to move Surabaya's people, particularly moslem to fight against British troops who had more sophisticated military power. Therefore the success of Bung Tomo's speech is expected to be an example for da'i in carrying out da'wah persuasively. This study aims to identify persuasive technique applied by Bung Tomo in his speech on 10 November 1945 in Surabaya. It uses a theory of Persuasive Technique. The methods is qualitive descriptive one. The data were taken from website documents and have undergone a data triangulation. The result of study shows that Bung Tomo in his speech on 10 November 1945 in Surabaya applied: (1) integration technique in showing the same fate with people of Surabaya, (2) pay-off technique in showing that the victory of war would come, (3) icing technique which was seen from his figurative language which was used by Bung Tomo, such as repetition and metaphor. Keywords: persuasive technique, speech of Bung Tomo 10 November 1945, da'wah 


\section{Pendahuluan}

Kegiatan dakwah adalah kegiatan komunikasi antara dai dengan mad'uw dalam rangka mengirimkan pesan dakwah. ${ }^{1}$ Menurut terminologi atau istilah, dakwah mengandung upaya menyebarluaskan kebenaran dan mengajak orang lain untuk mempercayainya. ${ }^{2}$ Sehingga dakwah bukan sekadar menyampaikan kebenaran, melainkan ada usaha agar seseorang tersebut mau mengikuti kebenaran tersebut. Oleh karena itu, seorang dai harus memiliki kemampuan komunikasi untuk memengaruhi seseorang atau sering disebut dengan komunikasi persuasif. Menurut Keraf persuasi merupakan seni berbicara yang bertujuan untuk meyakinkan orang lain untuk melakukan sesuatu sesuai dengan keinginan pembicara pada masa sekarang atau yang akan datang. ${ }^{3}$ Agar seseorang mampu melakukan komunikasi persuasif, maka seseorang perlu memahami tekniktekniknya. Dengan adanya teknik komunikasi persuasif, maka dapat membantu dai dalam memengaruhi dan meyakinkan mad'uw. Secara prospek dakwah juga akan semakin efektif bila dai mampu memengaruhi dan menggerakkan mad'uw yang berupa massa.

Tulisan ini menunjukkan satu realitas seseorang yang mampu menggerakkan massa hingga puluhan ribu orang. Realitas tersebut adalah Bung Tomo yang mampu menggerakkan warga Surabaya untuk berani bertempur melawan pasukan Inggris melalui pidatonya pada 10 November 1945 di

\footnotetext{
1 Sukriyanto, Kapita Selekta Dakwah (Suara Muhammadiyah, 2017), 40.

2 Mahmuddin, Manajemen Dakwah Rasulullah, (Jakarta: Restu llahi, 2004), 6.

${ }^{3}$ Gorys Keraf, Diksi dan Gaya Bahasa. (Jakarta: PT Gramedia Pustaka Utama 2010. Narasi dan Argumentasi. Jakarta: Gramedia, 2003), 118.
}

Surabaya. Dalam pertempuran tersebut Inggris mempersiapkan persenjataan canggih berupa tank ringan Stuart satu eskadron sedang artilerinya memiliki meriam-meriam 25 pound dan ho witser tiga koma tujuh, empat buah kapal perusak (destroyer), 12 mosquito dan Thunderbolt dan 21 tank Sherman dan sejumlah brencarrier. ${ }^{4}$ Di lain sisi pihak Indonesia hanya memiliki senjata-senjata sederhana, seperti mortir, meriam kaliber 75 mm, 12 tank. Melihat kondisi demikian, rakyat Indonesia di Surabaya tidak menyerah tetapi lebih memilih untuk bertempur melawan Inggris di Surabaya. Peneliti asal Inggris pernah menyatakan bahwa soal persenjataan, jelas lebih unggul pihak Inggris. Keunggulan pihak Indonesia yang sangat mencolok adalah semangatnya. ${ }^{5}$

Salah satu elemen penting penyebab semangat perjuangan rakyat Surabaya untuk berani melawan kehebatan pasukan Inggris tak dapat dipungkiri dipengaruhi oleh pidato Bung Tomo. Melalui Radio Pemberontakan, Bung Tomo mengobarkan semangat perjuangan rakyat Surabaya untuk melawan Sekutu yang ingin merebut kembali kekuasaan di Indonesia. Radio Pemberontakan disiarkan dari markas di jalan Mawar. Radio Republik Indonesia pun tak ketinggalan menyiarkan ulang orasi Bung Tomo ke kota besar lain, seperti Malang, Solo, dan Yogyakarta. ${ }^{6}$ Pidato tersebut dikenal sebagai pidato 10 November 1945. Frank Palmos, dalam bukunya, Surabaya 1945: Sakral Tanahku, menyatakan bahwa

\footnotetext{
${ }^{4}$ Suherly, T, Sejarah Perang Kemerdekaan Indonesia (Jakarta: Departemen Pertahanan Keamanan Pusat Sejarah ABRI, 1971), 15-16.

5 Ibid., 15.

${ }^{6}$ Setyarso, Budi dkk, Bung Tomo Soerabaja di Tahun 45 (Jakarta: KPG, 2016), 27.
} 
pidato Bung Tomo telah membuatnya menjadi salah satu pahlawan pertempuran Surabaya yang paling dicintai masyarakat. Sejarawan M.C. Ricklefs dalam bukunya, Sejarah Indonesia Modern, menyebut bahwa Bung Tomo adalah tokoh yang menggunakan radio setempat untuk menimbulkan suasana semangat revolusi yang fantastis ke seluruh penjuru kota. ${ }^{7}$ Keberhasilan Bung Tomo dalam mempersuasi massa untuk berani melawan Inggris dikarenakan kemampuan retorika persuasifnya yang mampu menangkap aspirasi dan semangat massa, khususnya pemuda, kelompok Islam, kalangan bawah dan jago kampung. ${ }^{8}$ Bila dilihat dari perspektif dakwah, pidato yang dilakukan Bung Tomo tersebut juga dapat dimasukkan ke dalam kategori dakwah. Menurut Dr. H. M. Quraish Shihab dakwah adalah seruan atau ajakan kepada keinsyafan atau usaha mengubah situasi yang lebih baik dan sempuma, baik terhadap pribadi maupun masyarakat. ${ }^{9}$ Pada konteks tersebut, Bung Tomo melakukan hal tersebut sebagai bentuk usaha mengajak warga Surabaya mempertahankan kemerdekaan, melepaskan diri dari penjajahan dan ketidakadilan, yang merupakan wujud dakwah dalam meraih kebaikan hidup bermasyarakat dan berbangsa.

Ditambah lagi terdapat simbol-simbol Islam di dalam Bahasa yang digunakan Bung Tomo dalam menyampaikan pidatonya di antaranya adalah bismillahirrahmanirrahim,

7 MYZ, "Peran Sentral Bung Tomo". Suara Muhammdiyah: Syiar Islam Berkemajuan. (Edisi 21, 2018), 6-8.

8 Ibid., 6-8.

${ }^{9}$ Samsul Munir Amin, Ilmu Dakwah, (Jakarta: Amzah, 2009), 4

${ }^{10}$ Setyarso, Bung Tomo Soerabaja, 40.
Allahu Akbar. Kalimat "Allahu Akbar" dan semboyan "merdeka atau mati", sangat akrab diteriakkan melalui corong radio. Teriakan itu berguna untuk menarik perhatian orang Islam Surabaya, yang oleh Bung Tomo dianggap sangat kuat tapi belum terjaring dalam gerakan melawan penjajah. ${ }^{10}$ Oleh karena itu, studi ini mengkaji teknik persuasif yang digunakan oleh Bung Tomo dalam pidato 10 November 1945. Hasil penelitian diharapkan dapat menjadi salah satu referensi atau teladan bagi para dai agar mengetahui teknik persuasif yang mampu menggerakkan mad'uw dalam konteks dakwah yang massanya besar.

Studi terhadap teknik persuasif pidato Bung Tomo belum pernah dilakukan sebelumnya. Memang terdapat studi yang berjudul "Tindak Tutur dalam Pidato Bung Tomo dan Implikasinya pada Pembelajaran Bahasa Indonesia di SMA". ${ }^{11}$ Namun perbedaan yang paling dasar adalah pada objek yang dikaji. Penelitian di atas objeknya adalah tindak tutur dalam pidato Bung Tomo, sedangkan studi ini, objeknya adalah teknik komunikasi persuasif dalam Pidato Bung Tomo. Ada juga penelitian yang objek penelitian adalah teknik komunikasi persuasif dengan judul, "Teknik Komunikasi Persuasif Ustadz Muhammad Nur Maulana dalam acara "Islam itu Indah" di Trans TV". ${ }^{12}$ Antara studi di atas dengan studi ini terdapat kesamaan dan perbedaan. Persamaannya adalah sama objek penelitiannya yakni

11 Rian Anggara, "Tindak Tutur dalam Pidato Bung Tomo dan Implikasinya pada Pembelajaran Bahasa Indonesia di SMA," (Skripsi, Universitas Lampung, 2016).

12 Muirodah, "Teknik Komunikasi Persuasif Ustadz Muhammad NUr Maulana dalam Acara "Islam itu Indah" di Trans TV." (Skripsi, Universitas Islam Negeri Walisongo, Semarang 2015). 
untuk mengetahui teknik persuasif. Namun perbedaan yang paling dasar adalah pada subjek penelitiannya. Penelitian di atas subjek penelitiannya adalah ceramah Ustaz Maulana, sedangkan studi ini subjek penelitiannya adalah Pidato Bung Tomo. Dari segi manfaat juga terdapat perbedaan, pada studi ini dapat memberikan sumbangan pemikiran bagi para peneliti bidang dakwah mengenai teknik komunikasi persuasif yang dapat digunakan seorang dai untuk menggerakkan massa untuk memperjuangkan kemerdekaan, atau dalam konteks saat ini untuk mempertahankan tanah air dan bangsanya dari jajahan pihak asing dalam berbagai bentuk.

Metodologi studi ini menggunakan pendekatan kualitatif dengan jenis deskriptif. Tujuan studi adalah mendeskripsikan teknik persuasif yang dilakukan oleh Bung Tomo dalam pidato 10 November 1945. Jenis data yang akan digunakan peneliti merupakan jenis data sekunder yang diperoleh dari studi pustaka melalui buku-buku/literatur ilmiah, pengetahuan umum, internet, jurnal ilmiah dan bahan bacaan lain yang berhubungan dengan permasalahan yang diteliti. Teknik pengumpulan data yang dilakukan adalah dokumentasi. Teknik analisis data yang digunakan adalah model Miles \& Huberman, ${ }^{13}$ yakni dengan tiga tahap: (1) Reduksi Data, pada konteks ini menghilangkan data-data yang tidak

13 Pawito, Penelitian Komunikasi Kualitatif (Yogyakarta : LkiS, 2007), 104-106.

14 Dik, " Isi Pidato Bung Tomo 10 November yang Bakar Semangat Arek-arek Surabaya, 'Allahu Akbar! MERDEKA!." diakses 10 November 2018, http://jogja.tribunnews.com/2018/11/10/isi-pidatobung-tomo-10-november-yang-bakar-semangat-arekarek-surabaya-allahu-akbar-merdeka?page $=4$.

15 Anwar Khumaini, "Ini pidato Bung Tomo yang Menggetarkan Jiwa Arek-Arek Suroboyo", diakses mengandung teknik persuasif, sehingga hanya fokus menampilkan data yang menunjukkan teknik persuasif. (2) Penyajian Data, pada tahap ini menyajikan data-data teknik persuasif yang dilakukan oleh Bung Tomo, yang telah direduksi dan ditriangulasi dalam bentuk narasi deskriptif. (3) Penarikan dan Pengujian Kesimpulan, pada tahap ini dilakukan pemaknaan terhadap kecenderungan dari sajian data, menarik dan menguji kesimpulan dari data-data tersebut. Keabsahan data dilakukan dengan triangulasi sumber. Terdapat tiga sumber data yang digunakan, yaitu: (1) Artikel yang ditayangkan oleh Tribunjogja.com dengan judul Isi Pidato Bung Tomo 10 November yang Bakar Semangat Arek-arek Surabaya, 'Allahu Akbar! MERDEKA! ${ }^{14}$, (2) Artikel yang ditayangkan oleh Merdeka.com dengan judul Ini pidato Bung Tomo yang menggetarkan jiwa arek-arek Suroboyo ${ }^{15}$, (3) Data audio di Youtube dengan judul Pidato Bung Tomo 10 November 1945. ${ }^{16}$

\section{Komunikasi Persuasif}

Kenneth E. Andresen dalam bukunya, Introduction Communication Theory and Practice mendefinisikan persuasi: " $A$ process of interpersonal communication in which the communicator seeks through the use of symbols to affect the cognition of a receiver and thus affect a voluntary change in attitude or action desired by the communicator." ${ }^{17}$ Bila diartikan ke dalam

tanggal $15 \quad$ Februari 2019 https://www.merdeka.com/peristiwa/ini-pidatobung-tomo-yang-menggetarkan-jiwa-arek-areksuroboyo.html

16 LanDHeart SK, "Pidato Bung Tomo 10 November 1945", diakses tanggal 15 Februari 2019. https://m.youtube.com/watch?v=aEvPBfM7OSQ1945 ".https://m.youtube.com/watch?v=aEvPBfM70SQ

17 Onong Uchjana Effendy, Hubungan Masyarakat (Bandung: Remaja Rosada, 2006), 79. 
bahasa Indonesia "Suatu proses komunikasi interpersonal dimana komunikator berupaya dengan menggunakan lambanglambang untuk memengaruhi kognisi penerima, jadi secara sengaja mengubah sikap atau kegiatan seperti yang diinginkan komunikator". Menurut Kamus IImu Komunikasi, komunikasi persuasif diartikan sebagai "Suatu proses untuk memengaruhi pendapat, sikap dan tindakan orang dengan menggunakan manipulasi psikologis sehingga orang tersebut bertindak seperti atas kehendaknya sendiri". ${ }^{18}$ Menurut De Vito usaha melakukan persuasi ini memusatkan perhatian pada upaya mengubah atau memperkuat sikap atau kepercayaan khalayak atau pada upaya mengajak mereka bertindak dengan cara tertentu. Persuasi juga dipahami sebagai usaha mengubah sikap melalui penggunaan pesan dan berfokus pada karakteristik komunikator dan pendengar. ${ }^{19}$ Dari beberapa pengertian di atas dapat disimpulkan bahwa persuasi adalah sebuah usaha untuk memantapkan atau mengubah suatu pemahaman atau sikap atau perilaku dari seseorang dengan menanamkan kesadaran tanpa adanya paksaan sedikitpun.

Tujuan komunikasi persuasif memiliki dua tingkat yaitu: (1) mengubah atau menguatkan keyakinan (believe) dan sikap (attitude) audiens, (2) mendorong audiens melakukan sesuatu/memiliki tingkah laku (behavior) tertentu yang diharapkan. ${ }^{20}$ Toir Kertapati dalam Bunga Rampai Asas-asas

\footnotetext{
18 Jalaluddin Rakhmat, Psikologi Komunikasi (Bandung: PT. Remaja Rosdakarya, 2008), 14.

19 Joseph A De Vito, Komunikasi Antarmanusia, Edisi Kelima (Jakarta: Karisma Publishing Group, 2011), 499. ${ }^{20}$ Riyanto dkk, Komunikasi Islam I: Perspektif IntegrasiInterkoneksi, (Yogyakarta : Galuh Patria, 2012), 51.
}

Komunikasi yang dikutip H. A. W. Widjaja mengatakan bahwa, persuasi merupakan salah satu bentuk komunikasi, oleh karena itu dengan sendirinya secara teoritis harus memiliki persyaratan tertentu: (1) pesanpesan/ajakan-ajakan yang disampaikan harus dapat menstimulus sesuatu pada sasaran; (2) bahwa pesan-pesan/ajakanajakan itu tentunya harus berisi lambanglambang komunikasi yang sesuai dengan daya tangkap, daya serap dan daya tafsir; (3) bahwa pesan-pesan/ajakan-ajakan harus dapat membangkitkan keperluan atau kepentingan (needs) tertentu pada sasarannya; (4) bahwa pesan-pesan/ajakan harus dapat membangkitkan harapanharapan tertentu dan sebagainya. ${ }^{21}$

Adapun unsur-unsur dalam suatu proses komunikasi persuasif menurut Sumirat \& Suryana adalah: ${ }^{22}$ Pertama, persuader. Persuader adalah orang atau sekelompok orang yang menyampaikan pesan baik secara verbal maupun nonverbal dengan tujuan untuk memengaruhi sikap, pendapat, dan perilaku orang lain. Di dalam komunikasi persuasif komunikator memiliki pengaruh yang cukup besar. Ada beberapa aspek dari komunikator atau persuader yang memiliki pengaruh terhadap komunikan: (a) kredibilitas komunikator, kredibilitas menyangkut dua hal yakni keahlian dan ketepercayaan. Mengenai keahlian dan ketepercayaan dikemukakan oleh Jalaluddin Rakhmat: ${ }^{23}$ Keahlian adalah kesan yang dibentuk komunikan tentang kemampuan

\footnotetext{
21 H. A. W Widjaja, Komunikasi: Komunikasi dan Hubungan Masyarakat (Jakarta: Bumi Aksara, 2002), 69.

22 Aen Istianah Afiati, Komunikasi Persuasif dalam Pembentukan Sikap (Skripsi-UIN Sunan Kalijaga, Yogyakarta, 2015), 25-27.

${ }^{23}$ Rakhmat, Psikologi Komunikasi , 260
} 
komunikator dalam hubungannya dengan topik atau pesan yang disampaikan kepada komunikan. Kepercayaan adalah kesan komunikan tentang komunikator yang berhubungan dengan watak; (b) daya tarik komunikator. Pada umumnya orang akan lebih tertarik kepada orang lain yang berpandangan sama dengan dirinya. Prinsip adanya kebersamaan ini menjadi salah satu faktor keberhasilan komunikasi. Kedua, persuadee. Persuadee adalah orang dan atau kelompok orang yang menjadi tujuan pesan yang disampaikan oleh persuader.

Ketiga, persepsi. Persepsi adalah sebuah proses untuk menginterpretasikan datadata. ${ }^{24}$ Persepsi dipengaruhi oleh faktorfaktor pengalaman, proses belajar, cakrawala, dan pengetahuan seseorang. Keempat, pesan persuasif. Menurut Littlejohn, pesan persuasif dipandang sebagai usaha sadar untuk mengubah pikiran dan tindakan dengan memanipulasi motif-motif ke arah tujuan yang telah ditetapkan oleh persuader. Makna memanipulasi dalam pernyataan tersebut bukanlah mengurangi atau menambah fakta sesuai konteksnya, tetapi dalam arti memanfaatkan fakta-fakta yang berkaitan dengan motif-motif khalayak sasaran, sehingga tergerak untuk mengikuti maksud pesan yang disampaikan kepadanya. ${ }^{25}$ Menurut Crider, ada beberapa syarat yang harus diperhatikan dalam isi pesan persuasif, yaitu: ${ }^{26}$ (a) dalam mengemas pesan persuasif tidak mengandung unsur paksaan, baik paksaan psikologis maupun

\footnotetext{
${ }^{24}$ Saverin J. Wenner, Teori Komunikasi: Metode dan Terapan di Dalam Media Massa. (Jakarta: Kencana, 2008), 83

25 M. Ritonga Jamaluddin, Tipologi Pesan Persuasif. (Jakarta: Indeks, 2005), 5
}

fisik; (b) pesan harus memotivasi. Suatu pesan yang dirancang hendaklah dapat mendorong khalayak sasaran untuk dapat menentukan pilihan dan keinginannya sendiri. Kelima, saluran persuasif. Saluran merupakan perantara ketika seorang persuadee menerima pesan dari persuader atau perantara ketika seorang persuader mengirimkan pesan hingga pesan diterima oleh persuadee. Saluran (channel) digunakan oleh persuader untuk berkomunikasi dengan berbagai orang, secara formal maupun nonformal, secara tatap muka (face to face communication) ataupun lewat media (mediated communication). Keenam, umpan balik dan efek. Menurut Sastropoetro umpan balik adalah jawaban atau reaksi yang datang dari komunikan atau datang dari pesan itu sendiri. Sedangkan efek adalah perubahan yang terjadi pada diri komunikan sebagai akibat dari diterimanya pesan melalui proses komunikasi. ${ }^{27}$

Menurut Purnawan EA agar persuasi dapat berlangsung sukses harus memperhatikan hal-hal sebagai berikut: ${ }^{28}$ (a) availability dan relevance. Yang dimaksud dengan availability adalah kemudahan komunikan dalam menerima pesan dan relevance adalah kesesuaian pesan yang diterima oleh komunikan berdasarkan situasi dan kondisi komunikan. Komunikan akan mudah menerima pesan persuader dan akan tergerak bila persuader menciptakan pesan yang sesuai dengan kondisi atau keadaan dari komunikan. Contohnya adalah pada orang tertentu ada keadaan tertentu orang

\footnotetext{
${ }^{26}$ lin Wahyuni, "Analisis Pesan Persuasif E-Wom Sosial Media," (Skripsi, Universitas Islam Negeri Yogyakarta, 2015), 12-14.

27 Soemirat dan Suryana. Komunikasi Persuasif. (Tangerang Selatan: Universitas Terbuka, 2016), hal. 238

${ }^{28}$ Wahyuni, "Analisis Pesan.," 12-14.
} 
kadang menginginkan argumen. Tetapi pada situasi yang lain orang tidak butuh argumen, tetapi hanya keindahan kata-kata; (b) memahami kondisi berpikir sasaran atau menentukan strategi pendekatan. Ada dua macam proses berpikir yakni heuristic dan systematic. Berfikir systematic adalah proses berpikir yang mengandalkan keruntutan logika. Berfikir heuristic adalah proses berpikir yang tidak terlalu melihat keruntutan logika tetapi lebih melihat keindahan atau kemasan pesan yang disampaikan oleh komunikator. Bila sasaran yang kita hadapi sedang dalam proses berpikir systematic maka diperlukan banyak argumentasi logis, data, pengalaman nyata, statistic, dan sebagainya. Bila sasaran berpikir heuristic, diperlukan banyak isyarat, bungkus ide berupa cerita, metafora (ungkapan), perlambang, sindiran, pujian dan kata-kata yang jitu, indah, dan menyenangkan; (c) memahami kebutuhan dari sasaran. Bila yang kita tawarkan sesuai dengan kebutuhan dari sasaran maka persuasi akan berlangsung sukses. Oleh karena itu persuader harus mencari kebutuhan yang paling diharapkan untuk dipenuhi dari persuadee; (d) attribution dan sequential request. Attribution adalah suatu proses dimana individu berusaha untuk menjelaskan alasan dari sikapnya, atau perilakunya. Menurut ahli psikologi setiap orang yang bersikap atau berperilaku pasti melakukan pertimbangan-pertimbangan, entah itu ke dalam dirinya sendiri atau persepsi dari luar dirinya (situasi). Ada dua macam attribution yakni eksternal dan internal. Attribution eksternal adalah sesuatu yang akan didapatkan dari luar bila dia melakukan atau tidak melakukan apa perintah persuader, biasanya bentuknya adalah berupa hukuman atau mendapatkan hadiah. Attribution internal terjadi karena tanggung jawab sendiri, alasannya datang dari orang itu sendiri. Sequential request adalah adanya sebuah permintaan yang disampaikan secara tidak langsung. Hal tersebut akan lebih efektif, karena orang yang diminta dengan cara ini tidak merasa didesak atau tertekan.

\section{Teknik Persuasif}

Istilah teknik berasal dari bahasa Yunani "technikos" yang berarti keterampilan atau keperigelan. Effendy menjabarkan teknikteknik komunikasi yang dapat dipilih. Teknikteknik tersebut adalah: Pertama, Teknik Asosiasi. Penyajian pesan komunikasi dengan cara menumpahkannya pada suatu objek atau peristiwa yang sedang menarik perhatian khalayak. Contohnya adalah dalam kampanye Pemilihan Umum yang lalu, ketenaran Rhoma Irama si Raja Dangdut yang sering membuat massa menjadi histeris, telah dipergunakan oleh salah satu partai politik untuk merebut hati rakyat. ${ }^{29}$ Kedua, Teknik Integrasi. Merupakan kemampuan komunikator untuk menyatukan diri secara komunikatif dengan komunikan. Ini berarti bahwa melalui katakata verbal maupun nonverbal komunikator menggambarkan bahwa ia "senasib" dan dengan karena itu menjadi satu dengan komunikan. Contoh dari teknik integrasi ini adalah penggunaan perkataan "kita", bukan perkataan "saya" atau "kami". "Kita" berarti "saya dan Anda", komunikator bersama komunikan yang mengandung makna bahwa yang diperjuangkan komunikator bukan

29 Onong Uchjana Effendy, Dinamika komunikasi. (Bandung: Remaja Rosada, 2008), 22-23. 
kepentingan diri sendiri, melainkan juga kepentingan komunikan. Ketiga, Teknik Ganjaran. Teknik ganjaran biasa disebut juga dengan pay-off technique. Teknik ganjaran (pay-off technique) adalah kegiatan untuk memengaruhi orang lain dengan cara mengiming-iming hal yang menguntungkan atau yang menjanjikan harapan. Kebalikan dari teknik ini adalah teknik "pembangkitan rasa takut" (fear arousing), yakni teknik yang bersifat menakut-nakuti atau menggambarkan konsekuensi yang buruk. Jadi, kalau pay-off technique menjanjikan ganjaran (rewarding), fear arousing technique menunjukkan hukuman (punishment).

Keempat, Teknik Tataan. Teknik tataan adalah upaya menyusun pesan komunikasi sedemikian rupa, sehingga enak didengar atau dibaca sehingga mampu menggerakkan sasaran sebagaimana disarankan oleh persuader. Teknik tataan biasanya disebut juga dengan Icing. Istilah icing berasal dari perkataan to ice, yang berarti menata kue yang baru dikeluarkan dari pembakaran dengan lapisan gula warna-warni. Kue yang tadinya tidak menarik itu menjadi indah, sehingga memikat perhatian siapa saja yang melihatnya. ${ }^{30}$ Teknik tataan ini sama seperti teknik sugesti yang dijelaskan dalam Gorys Keraf. Teknik sugesti ialah suatu usaha memengaruhi orang lain untuk menerima suatu keyakinan tanpa memberi suatu dasar kepercayaan yang logis pada orang yang ingin dipengaruhi. Biasanya dilakukan dengan menggunakan rangkaian kata yang menarik dan meyakinkan disertai nada suara yang penuh dan berwibawa. Teknik ini mempunyai ciri utama, yaitu bahwa teknik

\footnotetext{
30 Uchjana Effendy, Dinamika Komunikasi, 24

31 Ibid., 24.
}

ini dapat menciptakan kekuatan emosional yang kuat dalam memengaruhi seseorang. Kelima, Teknik Red-herring. Nama Redherring berasal dari nama ikan yang hidup di samudra Atlantik Utara. Jenis ikan ini terkenal dengan kebiasaannya dalam membuat gerak tipu ketika diburu oleh binatang lain atau manusia. Dalam hubungannya dengan komunikasi persuasif, teknik red-herring adalah seni seorang komunikator untuk meraih kemenangan dalam perdebatan dengan mengelakkan argumentasi yang lemah untuk kemudian mengalihkannya sedikit demi sedikit ke aspek yang dikuasainya guna dijadikan senjata ampuh dalam menyerang lawan. ${ }^{31}$

Pidato merupakan penyampaian gagasan, pikiran, atau informasi kepada orang lain secara lisan dengan metode-metode tertentu. Puspita menjelaskan bahwa secara umum ada tiga fungsi pidato, yaitu sebagai informatif, persuasif, dan rekreatif. ${ }^{32}$ Menurut Puspita ada beberapa prinsip terkait penyampaian pidato, yaitu adanya kontak atau hubungan antara pembicara dengan pendengar, suara atau vokal, gerak tubuh atau olah visual, dan pemakaian busana. ${ }^{33} \mathrm{Di}$ dalam konteks tulisan ini, pidato yang dilakukan oleh Bung Tomo menggunakan media radio, sehingga khalayak hanya bisa mendengarkan suara Bung Tomo dalam menyampaikan pidatonya. Dalam psikologi komunikasi suara disebut juga dengan pesan paralinguistik.

Rakhmat dalam bukunya Psikologi
Komunikasi menyatakan pesan
paralinguistik terbagi atas: nada, kualitas

32 R. Y. Puspita, Cara Praktis Belajar Pidato, MC, dan Penyiar Radio, (Yogyakarta: Notebook, 2014), 7.

33 Ibid., 28. 
suara, volume, kecepatan, dan ritme. ${ }^{34} \mathrm{Nada}$ menunjukkan jumlah getaran atau gelombang yang dihasilkan sumber bunyi. Nada biasanya juga disebut sebagai intonasi. Semakin banyak jumlah getaran dari sumber bunyi akan membuat nada semakin tinggi. Orang yang berbicara tanpa banyak perubahan nada disebut monoton. Nada dapat mengungkapkan kebahagiaan, ketakutan, kesedihan, kesungguhan, atau kasih sayang. Nada dapat memperteguh dampak kata yang kita ucapkan. Kualitas suara menunjukkan "tebal" atau "tipisnya" suara. Setiap orang memiliki kualitas suara tersendiri, sehingga kualitas suara mengungkapkan identitas dan kepribadiannya. Volume menunjukkan tinggi rendahnya suara. Bila marah atau menegaskan sesuatu, kita cenderung menaikkan volume suara. Sedangkan bila mengungkapkan perasaan sedih atau sayang kita merendahkan volume suara.

\section{Profil Singkat Bung Tomo dan Teks Pidatonya}

Bung Tomo lahir pada tanggal 3 Oktober 1920. Nama asli beliau adalah Sutomo, ayahnya bernama Kartawan Tjiptowidjojo. Pada tahun 1937, Menurut catatan William H. Fredrick dalam artikel pendeknya In Memoriam: Sutomo di jurnal Indonesia (April 1982) terbitan Universitas Cornell, Bung Tomo menjadi anggota Kepanduan Bangsa Indonesia (KBI), dan beliau termasuk segelintir orang yang meraih Scout Eagle. KBI merupakan organisasi kepanduan

\footnotetext{
${ }^{34}$ Rakhmat, Psikologi Komunikasi, 309.

${ }^{35}$ Setyarso, dkk, Bung Tomo., 71.

36 H. W. Frederick. Pandangan dan Gejolak Masyarakat Kota dan Lahirnya Revolusi Indonesia (Surabaya 1926-1946) (Jakarta: Gramedia, 1989), 315.
}

berasaskan kebangsaan yang terbentuk pada 1930 oleh dr. Moerwadi, alumnus School tot Opleiding Van Indische Artsen (STOVIA) atau Sekolah Kedokteran Hindia Belanda ${ }^{35}$. KBI memiliki peran penting bagi Bung Tomo untuk membentuk karakternya. Keterampilan kepramukaan yang diperoleh dari KBI antara lain: membaca peta/kompas, semafor, dan morse; memasak; menjahit; hidup di alam bebas; keterampilan berkomunikasi (berpidato), dan lain-lain. Sejak remaja Bung Tomo telah terkenal di kampungnya. Hal tersebut dikarenakan Bung Tomo mendapat lencana elang pada usia 16 tahun yang merupakan jenjang tertinggi yang diberikan oleh KBI. Hanya ada dua orang Indonesia yang mampu mencapai tingkat ini sebelum masa pendudukan Jepang. ${ }^{36}$

Pada tahun 1938, Bung Tomo menjadi redaktur mingguan Pembela Rakjat lalu Pemimpin Redaksi Kantor Berita Antara Surabaya. Pada tahun 1939 menjadi pembantu/koresponden untuk Surabaya, majalah Poestaka Timoer Yogyakarta, sebelum perang di bawah asuhan almarhum Anjar Asmara. Kemudian pada masa pendudukan Jepang di Indonesia, Bung Tomo bekerja di Kantor Berita Domei. Melalui Kantor Berita Domei ini, Bung Tomo dapat mengakses dan menyuplai informasi penting bagi kaum pergerakan kemerdekaan. Setelah Domei bubar, Bung Tomo mendirikan kantor berita Indonesia Antara di Surabaya bersama sejumlah rekan mantan wartawan Domei. ${ }^{37}$ Pada 12 Oktober 1945, Bung Tomo menjadi

\footnotetext{
${ }^{37}$ Eko Nur, "Persepsi Mahasiswa Tentang Tokoh Bung Tomo Dalam Perang Mempertahankan Kemerdekaan Indonesia Pada Pembelajaran Sejarah di SMA Negeri 1 Boja" (Skripsi : Universitas Negeri Semarang, 2016), 22.
} 
Pemimpin Barisan Pemberontak Rakyat Indonesia (BPRI). Dia memimpin di laskar itu sejak 12 Oktober 1945 hingga Juni 1947. Laskar perjuangan ini punya anggota hingga ke Kalimantan di masa revolusi. Pada 10 November 1945, Bung Tomo terlibat dalam Peristiwa 10 November 1945 di Surabaya. Pidatonya di Radio Pemberontakan yang mengobarkan semangat tempur rakyat Surabaya diingat banyak orang. Radio Pemberontakan disiarkan dari markas di jalan Mawar. Radio Republik Indonesia pun tak ketinggalan menyiarkan ulang orasi Bung Tomo ke kota besar lain, seperti Malang, Solo, dan Yogyakarta. ${ }^{38}$ Pada 21 Mei 1946, Bung Tomo adalah Kepala Perlengkapan di Kementerian Pertahanan. Selain itu Bung Tomo pernah juga menjadi Anggota Staf Gabungan Angkatan Perang Republik Indonesia. Pada tahun 1955, Bung Tomo diangkat menjadi Menteri Negara Urusan Bekas Pejuang Bersenjata \& anggota DPR. Pada 7 Oktober 1981, Bung Tomo meninggal dunia di Padang Arafah ketika naik haji. ${ }^{39}$

Berikut teks pidato Bung Tomo pada 10 November 1945:

"Bismillahirrohmanirrohim... Merdeka!!! Saudara-saudara rakyat jelata di seluruh Indonesia. Terutama saudara-saudara penduduk kota Surabaya. Kita semuanya telah mengetahui, bahwa hari ini tentara Inggris telah menyebarkan pamflet-pamflet yang memberikan suatu ancaman kepada kita semua. Kita diwajibkan untuk dalam waktu yang mereka tentukan, menyerahkan senjatasenjata yang telah kita rebut dari tangannya tentara Jepang. Mereka telah minta supaya kita datang pada mereka itu dengan mengangkat tangan. Mereka telah minta supaya kita semua datang pada mereka itu dengan membawa bendera putih tanda bahwa kita menyerah kepada mereka

38 Setyarso, Budi dkk, Bung Tomo Soerabaja di Tahun 45, 27.

39 Petrik Matanasi, "Bung Tomo: Persetan, Ora Dadi Jenderal Yo Ora Patheken", diakses tanggal 15
Saudara-saudara... Di dalam pertempuranpertempuran yang lampau. Kita sekalian telah menunjukkan bahwa rakyat Indonesia di Surabaya, pemuda-pemuda yang berasal dari Maluku, pemuda-pemuda yang berawal dari Sulawesi, pemuda-pemuda yang berasal dari pulau Bali, pemuda-pemuda yang berasal dari Kalimantan, pemuda-pemuda dari seluruh Sumatera, pemuda Aceh, pemuda Tapanuli, dan seluruh pemuda Indonesia yang ada di Surabaya ini. Di dalam pasukan-pasukan mereka masing-masing, dengan pasukanpasukan rakyat yang dibentuk di kampungkampung, telah menunjukkan satu pertahanan yang tidak bisa dijebol. Telah menunjukkan satu kekuatan sehingga mereka itu terjepit di mana-mana.

Hanya karena taktik yang licik daripada mereka itu saudara-saudara. Dengan mendatangkan presiden dan pemimpin-pemimpin lainnya ke Surabaya ini. Maka kita ini tunduk untuk memberhentikan pertempuran, tetapi pada masa itu mereka telah memperkuat diri, dan setelah kuat sekarang inilah keadaannya. Saudara-saudara kita semuanya, kita bangsa Indonesia yang ada di Surabaya ini akan menerima tantangan tentara Inggris itu.

Dan kalau pimpinan tentara inggris yang ada di Surabaya ingin mendengarkan jawaban rakyat Indonesia, ingin mendengarkan jawaban seluruh pemuda Indonesia yang ada di Surabaya ini. Dengarkanlah ini tentara Inggris! Ini jawaban kita, ini jawaban rakyat Surabaya, ini jawaban pemuda Indonesia kepada kau sekalian. Hai tentara Inggris! Kau menghendaki bahwa kita ini akan membawa bendera putih untuk takluk kepadamu. Kau menyuruh kita mengangkat tangan datang kepadamu. Kau menyuruh kita membawa senjata-senjata yang telah kita rampas dari tentara jepang untuk diserahkan kepadamu. Tuntutan itu walaupun kita tahu bahwa kau sekali lagi akan mengancam kita untuk menggempur kita dengan seluruh kekuatan yang ada.

Tetapi inilah jawaban kita, selama bantengbanteng Indonesia masih mempunyai darah

Februari 2019, https://tirto.id/bung-tomo-persetanora-dadi-jenderal-yo-ora-patheken-cxGZ 
merah yang dapat membikin secarik kain putih, merah dan putih, maka selama itu tidak akan kita mau menyerah kepada siapapun juga. Saudara-saudara rakyat Surabaya... siaplah keadaan genting! Tetapi saya peringatkan sekali lagi, jangan mulai menembak, baru kalau kita ditembak, maka kita akan ganti menyerang mereka itu. Kita tunjukkan bahwa kita ini adalah benar-benar orang yang ingin merdeka. Dan untuk kita saudara-saudara, lebih baik kita hancur lebur daripada tidak merdeka. Semboyan kita tetap, merdeka atau mati!!!

Dan kita yakin saudara-saudara, pada akhirnya pastilah kemenangan akan jatuh ke tangan kita, sebab Allah selalu berada di pihak yang benar. Percayalah saudara-saudara, Tuhan akan melindungi kita sekalian. Allahu Akbar! Allahu Akbar! Allahu Akbar! MERDEKA!!!"'40

\section{Teknik Persuasif dalam Pidato Bung Tomo}

Di dalam pidato Bung Tomo tersebut nampak secara tersurat bahwa tujuan dari pidato Bung Tomo adalah mengajak massa atau persuadee untuk berani dan semangat melawan tentara Inggris. Tujuan tersebut terlihat secara tersurat pada teks:

"Tetapi inilah jawaban kita, selama bantengbanteng Indonesia masih mempunyai darah merah yang dapat membikin secarik kain putih, merah dan putih, maka selama itu tidak akan kita akan mau menyerah kepada siapapun juga.

Saudara-saudara rakyat Surabaya... siaplah keadaan genting! Tetapi saya peringatkan sekali lagi, jangan mulai menembak, baru kalau kita ditembak, maka kita akan ganti menyerang mereka itu. Kita tunjukkan bahwa kita ini adalah benar-benar orang yang ingin merdeka. Dan untuk kita saudara-saudara, lebih baik kita hancur lebur daripada tidak merdeka. Semboyan kita tetap, merdeka atau mati!!!"

40 Anwar Khumaini, "Ini pidato Bung Tomo yang Menggetarkan Jiwa Arek-Arek Suroboyo", diakses tanggal $15 \quad$ Februari 2019, https://www.merdeka.com/peristiwa/ini-pidatobung-tomo-yang-menggetarkan-jiwa-arek-arek-
Dalam menyampaikan teks di atas, Bung Tomo juga menggunakan nada yang tinggi, berapi-api, dan juga pengucapan yang sangat lugas dan tegas. Hal tersebut akhirnya semakin menambah semangat arek-arek Surabaya dalam melawan Inggris. Melihat dari teks pidato tersebut juga bisa diketahui bahwa yang menjadi sasaran dari pidato Bung Tomo tersebut adalah rakyat Surabaya, dan seluruh pemuda Indonesia yang ada di Surabaya. Satu lagi yang juga menjadi sasaran pidato Bung Tomo yakni rakyat yang beragama Islam atau muslim, hal tersebut dapat diketahui dikarenakan pada pidato tersebut terdapat simbolsimbol Islam antara lain adalah Bismillahirohmanirrohim pada bagian awal pidato, kemudian terdapat kalimat "Allah selalu berada di pihak yang benar", dan yang terakhir ada kalimat "Percayalah saudarasaudara, Tuhan akan melindungi kita sekalian. Allahu Akbar! Allahu Akbar! Allahu Akbar!"

Selanjutnya yang perlu diketahui sebelum menganalisis teknik persuasif Pidato Bung Tomo adalah konteks atau kondisi yang melingkupi saat pidato tersebut disampaikan oleh Bung Tomo. Semua itu dimulai dari datangnya Inggris di Surabaya pada tanggal 25 Oktober 1945. ${ }^{41}$ Inggris datang di Surabaya awalnya dengan tujuan untuk melucuti senjata tentara Jepang, membebaskan para tawanan perang, dan memulangkan tentara Jepang. Namun ternyata Inggris memiliki tujuan lain yakni mengembalikan administrasi Indonesia kepada Belanda, dengan kata lain Inggris dan

\footnotetext{
suroboyo.html

41 Imran, Amrin, dkk, Indonesia dalam Arus Sejarah Jilid 6 (Perang dan Revolusi) (Jakarta: Ichtiar Baru Van Hoeven, 2013), 205.
} 
Belanda ingin kembali menjajah Indonesia, padahal Indonesia baru saja memperoleh kemerdekaan pada 17 Agustus 1945. Hal itulah yang akhirnya menimbulkan pertempuran-pertempuran kecil antara rakyat Surabaya dan Pasukan Inggris, yang pada akhirnya pada tanggal 30 Oktober 1945 Jenderal A.W.S. Mallaby tewas akibat pertempuran kecil dengan pejuang Surabaya. ${ }^{42}$

Tewasnya Jenderal Mallaby menimbulkan ketegangan baru antara pejuang Indonesia dengan Inggris. Kemudian Inggris mendaratkan divisi lima (tentara perang Inggris) di bawah pimpinan Mayor Jenderal Mansergh dari Malaya. Mansergh tiba-tiba memberikan ultimatum kepada penduduk Surabaya agar semua penduduk Indonesia di Surabaya yang memiliki senjata menyerahkan senjata mereka dan menyerah kepada Inggris dengan tenggat waktu selambat-lambatnya jam 06.00 tanggal 10 November 1945. Pada waktu itu keadaan rakyat yang ada di Surabaya sangat khawatir, bingung, dan was-was mengetahui ultimatum tersebut, apalagi mereka mengetahui bahwa pasukan Inggris memiliki perlengkapan perang yang canggih yang dibawa oleh divisi lima Inggris. Mengetahui keadaan yang sedemikian rupa, Bung Tomo pada tanggal 10 November 1945 melalui Radio Pemberontakan menyampaikan pidatonya tersebut. Dari konteks pidato seperti itu dan juga teks pidato di atas, bisa diketahui bahwa Bung Tomo memiliki harapan melalui pidato tersebut agar rakyat Surabaya berani melawan pasukan Inggris yang ingin sekali merenggut kemerdekaan Indonesia dan menjajah Indonesia.

\section{Teknik Integrasi}

Teknik integrasi merupakan kemampuan komunikator untuk menyatukan diri secara komunikatif dengan komunikan. Ini berarti bahwa melalui kata-kata verbal maupun nonverbal komunikator menggambarkan bahwa ia "senasib" dan dengan karena itu menjadi satu dengan komunikan. Pada teks pidato Bung Tomo 10 November 1945, Bung Tomo telah menggunakan teknik integrasi. Pada pidatonya, Bung Tomo menunjukkan bahwa ia "senasib" dengan seluruh pendengar radio yang menjadi komunikannya. Kesamaan nasib yang ditunjukkan oleh Bung Tomo adalah samasama merasakan ditipu oleh pasukan Inggris yang dalam ucapan tujuan awal mendarat ke Surabaya bertujuan baik, ternyata memiliki tujuan hendak mengembalikan kedudukan dan kekuasaan Belanda di Surabaya. Teknik ini ditunjukkan dalam teks berikut:

"Di dalam pasukan-pasukan mereka masingmasing, dengan pasukan-pasukan rakyat yang dibentuk di kampung-kampung, telah menunjukkan satu pertahanan yang tidak bisa dijebol. Telah menunjukkan satu kekuatan sehingga mereka itu terjepit di mana-mana. Hanya karena taktik yang licik daripada mereka itu saudara-saudara. Dengan mendatangkan presiden dan pemimpin-pemimpin lainnya ke Surabaya ini. Maka kita ini tunduk untuk memberhentikan pertempuran, tetapi pada masa itu mereka telah memperkuat diri, dan setelah kuat sekarang inilah keadaannya."

Kesamaan nasib yang kedua yang coba ditunjukkan oleh Bung Tomo adalah samasama dikenai ultimatum oleh Inggris yang isi ultimatumnya adalah mengancam akan membumihanguskan Surabaya beserta isinya bila tidak menyerah, dan menyerahkan senjata kepada Inggris dan

42 MYZ, “Peran Sentral Bung Tomo”, 6-8. 
Sekutu. Teknik ini ditunjukkan dalam teks pidato berikut:

"Bahwa hari ini tentara Inggris telah menyebarkan pamflet-pamflet. Yang memberikan suatu ancaman kepada kita semua. Kita diwajibkan untuk dalam waktu yang mereka tentukan, menyerahkan senjata-senjata yang telah kita rebut dari tangannya tentara Jepang. Mereka telah minta supaya kita datang pada mereka itu dengan mengangkat tangan. Mereka telah minta supaya kita semua datang pada mereka itu dengan membawa bendera putih tanda bahwa kita menyerah kepada mereka."

Kesamaan nasib ketiga yang ditunjukkan oleh Bung Tomo adalah dengan teknik menggunakan kata "Kita" di dalam pidatonya. Bahkan hampir di setiap kalimat selalu ada kata "Kita". Hal tersebut merupakan simbol bahwa nasib yang sedang dialami oleh Bung Tomo sama dengan seluruh rakyat Surabaya dan rakyat Indonesia. Berikut ini beberapa contoh pada teks pidato Bung Tomo yang menunjukkan kesamaan nasib: (1) "Kita diwajibkan untuk dalam waktu yang mereka tentukan, menyerahkan senjata-senjata yang telah kita rebut dari tangannya tentara Jepang. Mereka telah minta supaya kita datang pada mereka itu dengan mengangkat tangan. Mereka telah minta supaya kita semua datang pada mereka itu dengan membawa bendera putih tanda bahwa kita menyerah kepada mereka," (2) "Tetapi inilah jawaban kita, selama banteng-banteng Indonesia masih mempunyai darah merah yang dapat membikin secarik kain putih, merah dan putih, maka selama itu tidak akan kita mau menyerah kepada siapa pun juga," (3) "Tetapi saya peringatkan sekali lagi, jangan mulai menembak, baru kalau kita ditembak, maka kita akan ganti menyerang mereka itu. Kita tunjukkan bahwa kita ini adalah benar-benar orang yang ingin merdeka. Dan untuk kita saudara-saudara, lebih baik kita hancur lebur daripada tidak merdeka."

Bila dianalisis dengan teori faktor-faktor keberhasilan persuasif, pemilihan teknik dan pesan yang dipilih oleh Bung Tomo tersebut memenuhi faktor available dan relevance. Hal itu dikarenakan Bung Tomo mengangkat situasi dan kondisi yang saat itu memang benar-benar dirasakan oleh komunikan. Sehingga ketika Bung Tomo mengajak Rakyat Indonesia yang ada di Surabaya untuk melawan Inggris menjadi sangat relevance dengan situasi dan kondisi pada saat itu. Kondisi yang melingkupi saat itu yakni dimulai dari adanya tipuan dari Inggris yang ingin mengembalikan kedudukan Belanda di Surabaya dan pemberian Ultimatum dari Inggris. Kedua kondisi itulah yang membuat ajakan Bung Tomo untuk melawan Inggris sukses. Kedua kondisi tersebut diciptakan oleh Bung Tomo dengan kemasan teknik integrasi.

\section{Teknik Ganjaran}

Teknik ganjaran biasa disebut juga dengan pay-off technique. Teknik ganjaran (pay-off technique) adalah kegiatan untuk memengaruhi orang lain dengan cara mengiming-iming hal yang menguntungkan atau yang menjanjikan harapan. Kebalikan dari teknik ini adalah teknik "pembangkitan rasa takut" (fear arousing), yakni teknik yang bersifat menakut-nakuti atau menggambarkan konsekuensi yang buruk. Bung Tomo menggunakan pay-off technique di dalam teks pidato "Dan kita yakin saudara-saudara, pada akhirnya pastilah kemenangan akan jatuh ke tangan kita, sebab Allah selalu berada di pihak yang benar. Percayalah saudara-saudara, Tuhan akan melindungi kita sekalian." Ganjaran atau harapan yang dijelaskan oleh Bung 
Tomo kepada komunikan adalah harapan berupa kemenangan yang akan diraih dikarenakan ada Allah di pihak mereka, dan juga harapan bahwa Tuhan pasti akan memberikan perlindungan bagi mereka.

Bila dianalisis dengan teori faktor-faktor keberhasilan persuasif, pemilihan teknik dan pesan yang dipilih oleh Bung Tomo tersebut memenuhi faktor attribution. Attribution eksternal adalah sesuatu yang akan didapatkan dari luar bila dia melakukan atau tidak melakukan apa perintah persuader, biasanya bentuknya adalah berupa hukuman atau mendapatkan hadiah. Attribution internal terjadi karena tanggung jawab sendiri, alasannya datang dari orang itu sendiri. Terlihat jelas bahwa faktor Attribution eksternal-lah yang terpenuhi di dalam teknik ganjaran yang diterapkan oleh Bung Tomo. Yakni Bung Tomo menjanjikan hadiah berupa kemenangan. Selain itu, teknik dan pesan yang disampaikan di dalam pidato tersebut juga memenuhi faktor kebutuhan dari komunikan. Bung Tomo benar-benar memahami bahwa sebenarnya seluruh rakyat Indonesia yang ada di Surabaya hanya menginginkan sebuah kemerdekaan, tidak ingin dijajah lagi oleh bangsa manapun. Sudah cukup mereka merasakan dijajah oleh Belanda dan Jepang selama bertahun-tahun. Ditambah lagi rakyat baru merasakan kemerdekaan pada 17 Agustus 1945, oleh karena itu Bung Tomo mengetahui betul bahwa rakyat Surabaya pasti menginginkan kemenangan dan kemerdekaan.

Selain memahami kebutuhan dari komunikan, hal lain yang memiliki pengaruh terhadap kesuksesan Bung Tomo dalam menggerakkan massa adalah kredibilitas yang dimiliki oleh Bung Tomo di mata massa pendengar radio. Kredibilitas tersebut didapatkan oleh Bung Tomo sejak dia berumur 16 tahun. Di umur 16 tahun tersebut Bung Tomo telah mendapat lencana elang yang merupakan jenjang tertinggi yang diberikan oleh KBI. Hanya ada dua orang Indonesia yang mampu mencapai tingkat ini sebelum masa pendudukan Jepang. Selain itu Bung Tomo juga telah menjadi Pemimpin Barisan Pemberontak Rakyat Indonesia (BPRI). Dia memimpin di laskar itu sejak 12 Oktober 1945 hingga Juni 1947. Laskar perjuangan ini punya anggota hingga ke Kalimantan di masa revolusi sehingga telah dikenal oleh banyak orang.

\section{Teknik Tataan}

Teknik tataan adalah upaya menyusun pesan komunikasi sedemikian rupa, sehingga enak didengar atau dibaca sehingga mampu menggerakkan sasaran sebagaimana disarankan oleh persuader. Salah satu cara dalam menggunakan teknik tataan ini adalah dengan menggunakan gaya bahasa. Teknik tataan pertama yang digunakan oleh Bung Tomo ada pada teks, "Mereka telah minta supaya kita datang pada mereka itu dengan mengangkat tangan Mereka telah minta supaya kita semua datang pada mereka itu dengan membawa bendera putih tanda bahwa kita menyerah kepada mereka." Pada teks tersebut Bung Tomo menggunakan gaya bahasa perulangan atau repetisi. Yang pertama adalah mengulang kata-kata yang sama yakni "mereka telah minta supaya". Kata-kata itu diulang 2 kali. Selain itu Bung Tomo juga melakukan perulangan dengan kata yang berbeda namun intinya sama yakni pesan "menyerah". Untuk menyampaikan pesan "menyerah" Bung Tomo menggunakan kata "mengangkat tangan" dan kata "membawa bendera putih" yang mana kedua kata 
tersebut maknanya sama yakni "menyerah". Hal tersebut memiliki efek emosi yang lebih dalam. Ditambah dengan penyampaian dari Bung Tomo yang sangat heroik dan berapiapi.

Gaya Bahasa perulangan tersebut juga digunakan pada teks lain oleh Bung Tomo, yaitu: "Dan kalau pimpinan tentara inggris yang ada di Surabaya ingin mendengarkan jawaban rakyat Indonesia, ingin mendengarkan jawaban seluruh pemuda Indonesia yang ada di Surabaya ini. Dengarkanlah ini tentara Inggris! Ini jawaban kita, ini jawaban rakyat Surabaya, ini jawaban pemuda Indonesia kepada kau sekalian." Terlihat jelas bahwa Bung Tomo mengulang-ulang kata rakyat. Ditambah dengan penyampaian dari Bung Tomo yang sangat heroik dan berapi-api, mengakibatkan semangat rakyat semakin berkobar karena disebut berkali-kali.

Bung Tomo juga menggunakan teknik tataan yang ditunjukkan pada teks "Tetapi inilah jawaban kita, selama banteng-banteng Indonesia masih mempunyai darah merah yang dapat membikin secarik kain putih, merah dan putih, maka selama itu tidak akan kita mau menyerah kepada siapapun juga." Pada teks tersebut Bung Tomo mengemas pesan dengan menggunakan gaya bahasa metafora. Gaya Bahasa metafora adalah gaya Bahasa yang membandingkan suatu benda dengan benda lain secara langsung. Kata "Banteng-banteng Indonesia" memetaforkan "Rakyat Indonesia". Melalui kata tersebut Bung Tomo ingin menunjukkan bahwa rakyat Indonesia adalah orang yang siap melawan dan mempertahankan diri dengan sangat gigih selayaknya banteng. Ditambah dengan penyampaian dari Bung Tomo yang sangat heroik dan berapi-api, mengakibatkan hati pendengar radio menjadi semakin berkobar. Bukti keempat yang menunjukkan bahwa Bung Tomo menggunakan teknik tataan adalah penggunaan jargon-jargon yang mampu mengagitasi, yang mampu menambah semangat para pendengar untuk turun berjuang melawan pasukan Inggris. Jargon tersebut adalah "Merdeka atau mati !!" dan "Allahu Akbar! Allahu Akbar! Allahu Akbar! MERDEKA!!!" Jargon-jargon tersebut diucapkan di akhir pidato Bung Tomo yang didukung dengan pengucapan yang sangat berapi-api dan penuh semangat.

Dari penjelasan-penjelasan di atas menunjukkan bahwa Bung Tomo menggunakan teknik tataan ketika pidato. Kata-kata yang tersusun dengan indah dan memiliki efek yang sangat mendalam telah Bung Tomo ucapkan. Bila dianalisis dengan teori faktor-faktor keberhasilan persuasif, beragamnya karakter komunikan yang dihadapi, dan dengan konteks keterdesakan untuk merespon ultimatum, Bung Tomo memposisikan komunikannya memakai pola pikir heuristic. Pola berpikir heuristic adalah pola berpikir yang praktis, sederhana, tidak mampu berpikir secara sistematis. Dalam konsep yang telah dipaparkan sebelumnya, bila menghadapi komunikan yang menggunakan pola pikir heuristic diperlukan banyak isyarat, bungkus ide berupa cerita, metafora (ungkapan), perlambang, sindiran, pujian dan kata-kata yang jitu, indah dan menyenangkan. Sehingga sangat tepat bila Bung Tomo menggunakan teknik tataan dalam rangka mempersuasi massa. 


\section{Teknik Asosiasi.}

Selain teknik-teknik yang telah dijelaskan di atas. Terdapat teknik asosiasi juga digunakan oleh Bung Tomo. Teks pidato yang mengandung teknik asosiasi yang dimaksud adalah:

"Saudara-saudara... di dalam pertempuranpertempuran yang lampau Kita sekalian telah menunjukkan bahwa rakyat Indonesia di Surabaya, pemuda-pemuda yang berasal dari Maluku, pemuda-pemuda yang berawal dari Sulawesi, pemuda-pemuda yang berasal dari pulau Bali, pemuda-pemuda yang berasal dari Kalimantan, pemuda-pemuda dari seluruh Sumatera, pemuda Aceh, pemuda Tapanuli, dan seluruh pemuda Indonesia yang ada di Surabaya ini. Di dalam pasukan-pasukan mereka masingmasing, dengan pasukan-pasukan rakyat yang dibentuk di kampung-kampung, telah menunjukkan satu pertahanan yang tidak bisa dijebol. Telah menunjukkan satu kekuatan sehingga mereka itu terjepit di mana-mana Hanya karena taktik yang licik daripada mereka itu saudara-saudara Dengan mendatangkan presiden dan pemimpin-pemimpin lainnya ke Surabaya ini Maka kita ini tunduk untuk memberhentikan pertempuran, tetapi pada masa itu mereka telah memperkuat diri, dan setelah kuat sekarang inilah keadaannya. (Menunjukkan kelicikan dari Orang lain), sehingga bisa membangkitkan emosi untuk mau melakukan perlawanan, melawan Inggris."

Dari teks pidato Bung Tomo tersebut bisa diketahui bahwa Bung Tomo membuka ingatan lagi dari para komunikan bahwa mereka bersama-sama pernah mengalahkan Inggris, kemudian hal tersebut dihubungkan oleh Bung Tomo untuk kembali lagi berani melawan Inggris pada tanggal 10 November 1945.

\section{Kesimpulan}

Setelah melakukan analisis pada teknik persuasif pidato Bung Tomo 10 November 1945, berikut adalah hasil analisis teknik persuasif yang telah ditemukan: Bung Tomo menggunakan teknik integrasi dengan menunjukkan bahwa dia "senasib" dengan seluruh pendengar radio yang menjadi komunikannya. Ada tiga persamaan nasib yang ditunjukkan oleh Bung Tomo dalam pidatonya yaitu: (a) sama-sama merasakan ditipu oleh pasukan Inggris yang dalam ucapan tujuan awal mendarat ke Surabaya bertujuan baik, ternyata memiliki tujuan hendak mengembalikan kedudukan dan kekuasaan Belanda di Surabaya; (b) samasama dikenai ultimatum oleh Inggris yang isi Ultimatumnya adalah mengancam akan membumihanguskan Surabaya beserta isinya bila tidak menyerah, dan menyerahkan senjata kepada Inggris dan Sekutu; (c) menggunakan kata "Kita" di dalam pidatonya. Bahkan hampir di setiap kalimat selalu ada kata "Kita". Hal tersebut merupakan simbol bahwa nasib yang sedang dialami oleh Bung Tomo sama dengan seluruh rakyat Surabaya dan rakyat Indonesia.

Bila menggunakan teori faktor-faktor keberhasilan persuasif, pemilihan teknik integrasi dan pesan yang dipilih oleh Bung Tomo tersebut memenuhi faktor available dan relevance. Pada pidatonya Bung Tomo juga menggunakan teknik ganjaran yang biasa disebut dengan pay-off technique. Bung Tomo memengaruhi komunikannya dengan cara mengiming-iming sebuah harapan yakni berupa kemenangan perang dan perlindungan dari Tuhan. Bila menggunakan teori faktor-faktor keberhasilan persuasif, pemilihan teknik dan pesan yang dipilih oleh Bung Tomo tersebut memenuhi 
faktor attribution. Selain itu, teknik dan pesan yang disampaikan di dalam pidato tersebut juga memenuhi faktor kebutuhan dari komunikan. Bung Tomo benar-benar memahami bahwa sebenarnya seluruh rakyat Indonesia yang ada di Surabaya hanya menginginkan sebuah kemerdekaan, tidak ingin dijajah lagi oleh Bangsa manapun. Pada pidatonya Bung Tomo juga menggunakan teknik tataan. Bung Tomo berusaha memengaruhi pendengarnya dengan menyusun pesan pidatonya dengan penuh gaya bahasa yang indah dan enak didengar, ditambah dengan cara menyampaikan pidato yang sangat heroik. Dalam menerapkan teknik tataan Bung Tomo menggunakan gaya bahasa repetisi, gaya bahasa metafora, jargon dan juga menggunakan intonasi yang berapi-api dalam menyampaikan pidatonya. Pada pidatonya Bung Tomo tersebut, juga ditemukan bahwa Bung Tomo menggunakan teknik asosiasi. Dalam menerapkan teknik asosiasi ditandai dengan Bung Tomo mengingatkan kembali bahwa sebelumnya perjuangan Rakyat Surabaya melawan Inggris pernah sukses dan telah mampu mengalahkannya. Kemudian fakta tersebut dihubungkan dengan keadaan saat ini yakni keadaan ketika Inggris mengultimatum rakyat Surabaya, agar rakyat Surabaya bersedia melawan Inggris lagi.

Dari hasil penelitian ini diharapkan dapat menjadi penambah referensi bagi para dai dalam melakukan dakwah agar dapat memengaruhi dan menggerakkan mad'uw berupa massa dengan jumlah yang sangat banyak.

\section{Bibliografi}

Afiati, Aen Istianah. "Komunikasi Persuasif dalam Pembentukan Sikap." Skripsi, UIN Sunan Kalijaga, Yogyakarta, 2015.

Amin, Samsul Munir. Ilmu Dakwah. Jakarta: Amzah. 2009.

Anggara, Rian. "Tindak Tutur dalam Pidato Bung Tomo dan Implikasinya pada Pembelajaran Bahasa Indonesia di SMA." Skripsi. Universitas Lampung, Bandar Lampung, 2016.

De Vito, Joseph A. Komunikasi Antarmanusia, Edisi Kelima. Jakarta: Karisma Publishing Group, 2011.

Dik. "Isi Pidato Bung Tomo 10 November yang Bakar Semangat Arek-arek Surabaya, 'Allahu Akbar! MERDEKA!", Februari 15, 2019. http://jogja.tribunnews.com/2018/11/10/isipidato-bung-tomo-10-november-yang-bakar-semangat-arek-arek-surabaya-allahuakbar-merdeka?page $=4$. 2018,

Effendy, Onong Uchjana. Dinamika komunikasi. Bandung: Remaja Rosada, 2008. . Hubungan Masyarakat. Bandung: Remaja Rosada, 2006.

Frederick H, W. Pandangan dan Gejolak Masyarakat Kota dan Lahirnya Revolusi Indonesia (Surabaya 1926-1946). Jakarta: Gramedia, 1989.

LanDHeart SK. "Pidato Bung Tomo 10 November 1945", Februari 15, 2019. https://m.youtube.com/watch?v=aEvPBfM7OSQ

Imran, Amrin, dkk. Indonesia dalam Arus Sejarah Jilid 6 (Perang dan Revolusi). Jakarta: Ichtiar Baru Van Hoeven, 2013. 
Jamaluddin, M. Ritonga, Tipologi Pesan Persuasif. Jakarta: Indeks, 2005.

Keraf, G. Diksi dan Gaya Bahasa. Jakarta: PT Gramedia Pustaka Utama. 2010 Narasi dan Argumentasi. Jakarta. Gramedia, 2003.

Khumaini, Anwar. "Ini pidato Bung Tomo yang Menggetarkan Jiwa Arek-Arek Suroboyo," Februari 15, 2019. https://www.merdeka.com/peristiwa/ini-pidato-bung-tomo-yangmenggetarkan-jiwa-arek-arek-suroboyo.html

Mahmuddin. Manajemen Dakwah Rasulullah. Jakarta: Restu Ilahi, 2004.

Matanasi, Petrik. "Bung Tomo: Persetan, Ora Dadi Jenderal Yo Ora Patheken." Februari 15, 2019, dari https://tirto.id/bung-tomo-persetan-ora-dadi-jenderal-yo-ora-patheken-cxGZ

Muirodah. "Teknik Komunikasi Persuasif Ustadz Muhammad NUr Maulana dalam Acara "Islam itu Indah" di Trans TV. Skripsi, Universitas Islam Negeri Walisongo, Semarang, 2015.

MYZ. "Peran Sentral Bung Tomo". Suara Muhammdiyah: Syiar Islam Berkemajuan. Edisi 21. 2018

Nur, Eko. "Persepsi Mahasiswa Tentang Tokoh Bung Tomo Dalam Perang Mempertahankan Kemerdekaan Indonesia Pada Pembelajaran Sejarah di SMA Negeri 1 Boja." Skripsi : Universitas Negeri Semarang, 2016

Pawito. Penelitian Komunikasi Kualitatif. Yogyakarta : LkiS, 2007.

Puspita, RY. Cara Praktis Belajar Pidato, MC, dan Penyiar Radio. Yogyakarta: Notebook, 2014.

Rakhmat, Jalaluddin. Psikologi Komunikasi. Bandung : PT. Remaja Rosdakarya, 2000.

Riyanto, Mahfud, Waryani Fajar dan Mokhammad. Komunikasi Islam I: Perspektif IntegrasiInterkoneksi. Yogyakarta : Galuh Patria, 2012.

Setyarso, Budi dkk. Bung Tomo Soerabaja di Tahun 45. Jakarta: KPG, 2016.

Soemirat dan Suryana. Komunikasi Persuasif. Tangerang Selatan: Universitas Terbuka, 2016.

Suherly, T. Sejarah Perang Kemerdekaan Indonesia. Jakarta: Departemen Pertahanan Keamanan Pusat Sejarah ABRI, 1971.

Sukriyanto. Kapita Selekta Dakwah. t.t: Suara Muhammadiyah, 2017.

Wahyuni, lin. "Analisis Pesan Persuasif E-Wom Sosial Media." Skripsi, Universitas Islam Negeri, Yogyakarta, 2015.

Wenner, Saverin J. Teori Komunikasi: Metode dan Terapan di Dalam Media Massa. Jakarta: Kencana, 2008.

Widjaja, H. A. W. Komunikasi: Komunikasi dan Hubungan Masyarakat. Jakarta: Bumi Aksara, 2002. 